\title{
Internet Aggregators Constructing the Political Right Wing in Japan
}

\author{
Muneo Kaigo \\ Faculty of Humanities and Social Sciences, University of Tsukuba, Ibaraki, Japan \\ mkaigo@japan.tsukuba.ac.jp
}

\begin{abstract}
This paper overviews the condensation mechanism of the information flow from Net-uyoku (cyberspace rightwingers) entries in the Ni-Channel messaging forum of Japan that are edited into summary blogs of Ni-Channel called Matome Saito, and the aggregation of the numerous Matome Saito, with a focus on Japan and the December 2012 election. I examined the tone of argument of the Matome Saito aggregation and found 148 politically related thread blog pages and found that the Matome Saito use supportive language in relation to the Liberal Democratic Party of Japan but negative towards other parties. The analysis also found the blog pages generally reflected Net-uyoku tone of argument found in the $\mathrm{Ni}$-Channel. This study suggests that these Matome Saito can be considered to be an emergence of a new type of political agenda-setters in Japanese politics and may have a potential impact on the formation of public opinion in Japan.
\end{abstract}

Keywords: Japan, 2012 General Election, House of Representatives, Ni-Channel (2Ch), Matome Saito, Aggregator

Acknowledgement: This work was supported by JSPS KAKENHI Grant Number 253309394.

T he transition to Web 2.0 has allowed for many individuals to transmit and upload information onto the Internet, however this breakthrough in information technology has lead to an enormous amount of increase in total information. This evolution has made searching or receiving relevant information among a wide variety of topics very difficult, even for the adept Internet users. To overcome these inefficiencies, aggregator sites have become popular tools for gaining information.

Famous aggregator sites such as Reddit and Digg are popular among the English speaking Internet users, who wish to gain information efficiently about popular topics that are being discussed in various locations in the Internet that may interest them. In Japan, other than the main popular portals such as Yahoo and Google news, there are similar sites called Matome Saito (summary sites) that are individually managed blogs that collect and edit information and discussions among Internet users about various popular topics. Similar to the U.S. aggregator sites, the Matome Saito in Japan collect information about scandals, pictures, videos, along with news information about politics and society that are popular or relevant to Japanese. The difference is that the Matome Saito are blogs maintained by individuals that mainly scan popular topics in the Ni-Channel (Ni-Channeru or Ch2) anonymous bulletin board site, and present the information efficiently and concisely so that one can navigate and select information from the colossal amount of information that is being discussed in the various sections of the Ni-Channel forum. The information is rapidly and accurately procured, disseminated and delivered to those that view these blogs, often providing news quicker than the main news pages of the popular portals in Japan such as Yahoo or Google, therefore, the Matome Saito are considered to be an efficient and reliable source of information, and at times, superior than the portals.

The Matome Saito also exist as a potential tool for providing important political information and comments about news for those scanning cyberspace who are not traditionally knowledgeable about politics. The information in the blogs is a convenient guideline for gaining political information, however many potential problems also exist, because they are personally edited blogs 
of entries by anonymous users that do not adhere to any social or ethical norms of journalism. The management of such Matome Saito by a single individual everyday is close to impossible, so the use of wikis allows for several people to add and renew information to the Matome Saito. These individuals can participate in creating and maintaining these sites that require the constant effort of selecting and editing topics from the Ni-Channel. Although these Matome Saito mainly collect and edit popular information from anonymous bulletin board sites, the information on Matome Saito is not always balanced, and is sometimes heavily inclined towards to the skewed political views of the few individuals that are managing these sites and are using many entries that may be the words of the Internet right-wingers.

The Japanese cyberspace right-wingers or Net-uyoku have become an everyday term among the Japanese mainstream media and population. The social and political views in Matome Saito portray specific vocabulary and language that are characteristic of those right-wingers. They are empathetic to the conservative Liberal Democratic Party (LDP) politicians that are associated to the Net-uyoku interests in a similar style. The language used in these Matome Saito also frequently presents discord and antipathy directed towards the mass media in Japan so they are not supportive of the far-right Japan Restoration Party which houses Tōru Hashimoto, the former television celebrity.

The Matome Saito, that are prevalent throughout Japanese cyberspace, are popular, and they provide useful sophistry, and build aggressive arguments against the individuals and groups that oppose the Liberal Democratic Party and ideology aligned to the conservative politicians in the Liberal Democratic Party. There are smartphone apps that provide the information on these sites tailored for optimum results on these devices (Figure 1). This allows for many users to conveniently receive common information and political viewpoints via a "meso" medium among popular topics.

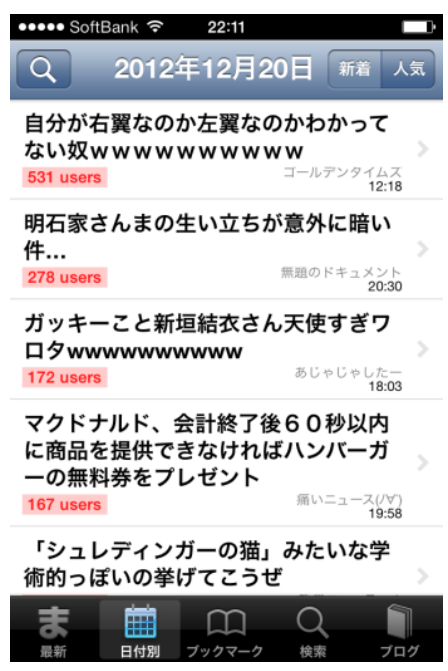

Figure 1. MT2 app view of most popular edited thread blog titles of the day

In result, the Matome Saito are creating information sources that provide concisely edited news commentary on various news topics. However, the political news on the Matome Saito have been observed to be sympathetic to the opinions of the Liberal Democratic Party due to support by the Net-uyoku, and negative of the other parties such as the Democratic Party of Japan (DPJ) and the Japan Restoration Party that are positioned more on the left and right of the political spectrum but not supported by the Net-uyoku. Based on these assumptions, this study will probe the following two hypotheses and research question.

H1: The top political news topics on Matome Saito use supportive language in relation to the Liberal Democratic Party of Japan.

H2: The top political news topics on Matome Saito use opposing language in relation to political parties other than the Liberal Democratic Party of Japan. 
RQ: What climate of opinion are the top political news Matome Saito blog pages creating during the time of the Japanese General Election of the House of Representative in 2012?

This paper examines the tone of argument in the Japanese Matome Saito aggregators in relation to political issues preceding the December 2012 Japanese General Election of the House of Representatives and will discuss the results in relation to the content of the Matome Saito aggregators and Net-uyoku.

\section{Net-uyoku - Japanese Rightwingers in Cyberspace and the Aggregation Process of the Matome Saito Aggregators in Japan}

The Net-uyoku or Internet right-wingers have become a prominent voice in Japanese bulletin boards such as the Ni-channel that display hostile language and tendencies. They are often abbreviated as Net-uyo and voice right-wing tendencies in cyberspace. They are classified separately from the conservatives and ultra-nationalistic groups in Japan that are more visible in the mainstream media and real life and exist as a separate entity in cyberspace only. According to an empirical study by Tsuji (2008), those who are Net-uyoku have been established to display the three following traits. They are 1) anti-South Korean and anti-Chinese, 2) support a) politicians that honor the Yasukuni Shrine, b) revision of Article 9 of the Japanese Constitution, c) enforcing patriotism education in Japanese primary and middle schools, singing the national anthem and hoisting the national flag in schools, and are 3) active in online behavior discussing or adding entries about political and social issues in cyberspace. The New York Times has labeled them as a group of younger Japanese people who are trying to oust foreigners out of Japan because they are disappointed by their current living situation (Fackler, 2010). Many theories and different definitions exist, however, the real face of Net-uyoku is unknown, and their identity is still in flux, as the possibility exists where they may be ordinary citizens just fanning out nationalism in the Ni-channel (Mie, 2013). Their presence has been acknowledged for many years, as early as the 1990s, however, legal action against their activities has not seen any change as civil suits were ineffective in winning any results (Johnston, 2006).

Tsuji's (2008) study has found that approximately 1.3 percent of the heavy Internet users in Japan can be considered to fall into the category of Net-uyoku. Considering the approximate total number of people from Tsuji's survey, the influence of the Net-uyoku is being viewed as far greater than in reality. At the same time, Tsuji is cautious about discounting their effect totally, as people may be misled to believe that the public opinion in cyberspace may be a veritable reflection of the majority, especially among those that have less interest in politics. From this caveat, one must also be cautious of not ignoring the prominence of Japan's largest single Internet bulletin board forum, the Ni-channel and how information there is being condensed through aggregation into the Matome Saito.

The Ni-channel' is Japan's most widely known single free access Japanese Internet forum, with over ten million people accessing it each month. Alexa data on traffic ranks it $23^{\text {rd }}$ in Japan and $343^{\text {rd }}$ globally. Discussion board topics range from international news, business, shopping, health concerns, and education to more controversial topics such as inside information leaks from dissatisfied employees of companies and from journalists seeking to provide sensitive information not publishable in the mainstream media (Kaigo \& Watanabe, 2007).

The Ni-Channel is famous for its numerous ignominious entries and incidents (Onishi, 2004). Indeed, with all its dysfunctional aspects, Ni-Channel is a well-known synonym for "Internet pandemonium" in Japan. Risqué or taboo subjects that are usually not discussed in normal face-toface communication in Japan are popular topics in Ni-Channel. Another characteristic of the $\mathrm{Ni}$ Channel forum is the frequency of direct confrontation among users, in a culture where verbal conflict is considered antisocial and is characteristically avoided in face-to-face communication. $\mathrm{Ni}$ Channel has also been a center for venting hatred and discrimination towards others, and it has been associated with illegal and criminal activities. The free access and anonymity of the users shelters the identities of those who post entries; as a consequence, the content of Ni-Channel often 
appears to reflect some of the worst examples of human communication behavior. The Ni-Channel is moderated by the general public, or more specifically by a volunteer group in which some individuals are self-elected and others are picked from other users. Each thread is limited to 1,000 postings, and another thread must be created if the discussion continues. Usually, the original thread name will continue to be used, with a "Part 2" added, meaning that 1,000 postings have already been made and that the thread is a continuation of a prior thread (Kaigo \& Watanabe, 2007).

The Ni-Channel preserved the anonymous posting system, in contrast to the system of most Internet forums in other nations that requires registration and email verification. Although a name field is available in Ni-Channel threads, it is hardly ever used for actual names. This allows people to post and deliver information without taking any risks by revealing their identity. It thus creates an atmosphere in which people are able to discuss anything in absolute honesty, mainly due to the fact that nobody knows who is involved in the discussion. Many advocates of the Ni-Channel Internet forum cite this aspect to justify the important social role and function the forum serves (Kaigo \& Watanabe, 2007).

The Matome Saito, or edited Ni-Channel thread blogs aggregate information of this largest bulletin board in Japan. The edited Ni-Channel thread blogs pick up topics that are popular especially hot threads that are getting many entries and viewers. In the Ni-Channel system, a posting in a thread will either bump up the thread's numerical position in the thread list or not change the position in the thread list, depending on what is typed in the email field of the posting. Posts with an email field with 1) an actual email address or 2) the word "age," or 3) that are left empty by the post author will bump up or raise the thread to a higher position in the list, whereas an email field in which the post author has entered the word "sage" will have no effect on changing the position of the thread in the list. Threads higher up in a thread list tend to be viewed more frequently than those lower the list, and as a result, attract more trolls, spam, and posts that are devoid of meaning. Users in active threads who wish to continue their discussions without unnecessary attention or nuisance deliberately use "sage" for their postings, and this has become the mainstream custom for many active threads. Inactive threads or threads with only "sage" postings get pushed down the thread list by newer threads or other threads that have been bumped up and are eventually pushed out of the thread list, unless an "age" post bumps the thread up the list. The older threads are sent to a paid archive and after some time, get deleted. The Matome Saito, or edited Ni-Channel thread blogs subsequently pick up the threads that are getting the most attention, or that fall into the category that interests the editor, and will delete the trolling and ascii art that is rampant in these threads to improve readability, change the color and/or enlarge the font of interesting comments or comments made by the thread originator and upload these as a blog. In this way, the Matome Saito is a blog that conveys information in the Ni-Channel to a wider audience than the typical Ni-Channel user. The blogs are updated daily, and are mediated to a large audience, with rapid diffusion of hot topics. The blogs edit user-generated content of the Ni-Channel into a package with much better readability. Through affiliate programs or AdSense (Google) editors of popular blogs can gain revenue through advertising so the blogs compete with each other to gain more readers by improving readability, add more controversy and alter titles to make the edited threads more attractive. Twitter and other types of social media simply post link to these blogs and proliferate knowledge on these blogs.

The content on Matome Saito can be divided into news and non-news content. The non-news content, for instance, may be about interesting exchanges between Ni-Channel users, material such as stories or personal episodes, or pictures, videos. News content can be from the $\mathrm{Ni}$ Channel News Sokuhoban (News flash bulletin board), which is a popular bulletin board. News on this bulletin board can range from news agencies and newspapers or can be about anime or sports. What is noteworthy about information stemming from this bulletin board is how Ni-Channel users will read specific news, and decode the news and comment in a way to re-create the news into neta (new material) that can receive more liking by the majority of the Ni-Channel users. The 
exchanges among the users can become new material, or the way the title is presented can lead to entries flooding the thread.

Kashiwabara (2012) illustrated in his study how instead of the traditional Japanese mass media, the Matome Saito were central in initially disseminating the November 2010 YouTube video leak of the Chinese fishing vessel ramming into the Japanese Maritime Self-Defense Force vessel in the previous month. The videos of the Chinese fishing vessel ramming into the Japanese Maritime Self-Defense Force vessel in October 2010, were not to be made public through a diplomatic agreement between Japan and the People's Republic of China to avert a worsening of relations between the two nations. However, the videos were leaked onto YouTube and subsequently, the $\mathrm{Ni}$-Channel and Matome Saito quickly picked up this information and acted as a catalyst to quickly spread the existence of these videos throughout the Internet. As more users became aware of these videos and information became diffused more widely, the popularity of this issue became visible in the rankings of the Ni-Channel and in the Matome Saito. Such content in the Ni-Channel tends to be flooded with comments, or become a matsuri ("festival" of flaming) as Tsuda (2009) has described. As the Matome Saito were instrumental for diffusion of this news, in result, this incident dramatically increased the perceived reliability and trustworthiness of Matome Saito. Among some Japanese, the Matome Saito are now considered to have higher credibility than the legacy traditional mass media due to the 2010 video incident, because the mass media initially cooperated with government in not showing the footage of these videos and in effect were considered collaborators of the government and also Pro-Chinese and Anti-Japanese for not actively disclosing these videos (in agreement with the tone of argument of Net-uyoku). The Matome Saito do not comply with the government and are not regulated, so information is viewed to be more objective because they do not need to adhere to legal, social or other professional norms or regulations, and supposedly provide both sides of any issue.

A "Matome Saito no Matome" is an aggregator of these numerous edited Ni-Channel Matome Saito blog pages. The Matome Saito aggregator will either list the most recent or most popular blog pages based on hatena bookmarks, which are online bookmarks that are shared through a website, as a social bookmarking service. The Matome Saito aggregator will have many blogs, for instance, MT2 has over 150 registered as Matome Saito. The Matome Saito aggregator differs from popular aggregators in the U.S. such as Reddit and is also different from Google News in the aspect of having an actual human editor creating the blog instead of having a computer algorithm, which is used by many of the search engine portal news sites.

\section{Political Information Aggregation and Matome Saito no Matome Aggregators}

As people now have so many different media choices for news information (Chaffee \& Metzger, 2001; Williams \& Delli Carpini, 2004), one does not solely rely on traditional media. As a general trend in many nations, those in the younger generation have a preference of getting their news information from online sources rather than traditional media (Coleman \& McCombs, 2007). More people are using the Internet as an information source, however, the evaluation and the exact role of the Internet as an information source is in dispute. In the past, Hindman (2009) has quoted that the potential of the Internet as a political information source would be short-circuited by citizen disinterest in politics (Jennings \& Zeitner, 2003), and that the Internet would be effective for those who already have interest but not for those with apathy towards politics (Prior, 2007). On the other hand, Tolbert and McNeal (2003) argue that those that have access to online news will be more likely to vote, and having access will more likely mobilize those who were inactive prior to Internet access (Kreuger, 2002), contrary to the results of low voting rates in many national and regional elections where Internet access is prevalent.

Hindman (2009) explains how the Internet has made political inequalities already existing more equal, but on the other hand, it has led to newer inequalities. Citizen participation in political voices heard on the Internet may be one of these inequalities, as we can observe in the case of the aggregators in Japan. Hindman (2009) states how linking structures lead to the concentration of 
certain information that is contrary to the assumption that the Internet will allow for diversification of voices. If only a few visitors arrive at a website, it is narrowcasting while the websites that receive the most visitors continue to expand their viewership/readership. The vastness of available political information and the lack of cognitive resources to process this wealth of information leads people to depend on a limited, handful of convenient sources of political information. In such, Hindman (2009) claims that websites have a tendency to be a "winner takes all", so concentration of online access of audience share due to the nature and structure of the Internet is inevitable, however, Hindman mentions that the Internet has not entirely displaced the legacy media or traditional media.

The case may be similar among younger Japanese in their teens and twenties that have begun living in a different information environment than the older generation above 30 years old. The younger Japanese are not so dependent on traditional media when taking into consideration the many different types of information that caters to their needs. The most common way to access news for younger Japanese is through portal sites on mobile devices in recent years (Dentsu Public Relations, 2012). Younger Japanese are less dependent on traditional media. In addition, political information in each of the major legacy media outlets has been often viewed to be supporting a specific (mostly liberal, left-wing) political view in Japan. In result, many Japanese in their teens and twenties have been reluctant to support those views or subscribe to these legacy media outlets, especially if they have been disinterested or had apathy towards politics in the past and see a grim future that is the fault of the liberal or left-wing policies in control of the government.

The Ni-Channel and the Matome Saito blogs may have transformed this disinterest towards politics among the youth, by providing additional information or viewpoints similar to their voices on certain political themes. Along with various miscellaneous topics, political news is included in the Matome Saito for audiences that have traditionally had no interest at all about politics. Ordinary individuals create the content on Ni-Channel, and the Matome Saito blogs edit the information to cater to the political inclination of the editor or popular view. The content found on the Ni-Channel has an inherent polarizing nature through anonymity and traditionally display direct and hostile interaction among those that make entries (Onishi, 2004; Johnston, 2006; Fackler, 2010; Mie, 2013). However, this content style may lead the audience to feel the Ni-Channel is more truthful and objective than the traditional media outlets which try to use more indirect expressions when delivering the news (ie. in news about accidents, when the victim has had both arms and legs severed may be expressed as "the victim is in serious condition" in Japanese mass media). Hindman (2009) has indicated how blogs are now the new elite media, although in the case of the Matome Saito, the content is not so much what the blogs originally create, but rather how they edit available user-generated content of the Ni-Channel forum that uses politically polarized language. This creates an image of the blogs to be honest political opinions and discussions of the ordinary citizens due to the commentary information presenting both sides of any issue. People browsing the Matome Saito sense that they are able to access what ordinary citizens perceive about each issue through the comments, in contrast to reading a column in the newspaper or the opinion of an educated expert on television. Therefore the Matome Saito differ from Hindman's view of blogs, in the sense that they are not the original content of a select elite, but they are the popular blogs of people who want to access and read the words of other people on various issues that concern the population at the time. The Matome Saito aggregators then list up the popular blogs, and let people know which topic is "hot" or popular. The problem lies in the fact that the entries of these threads are far from a public sphere. Cass Sunstein (2001) and Yochai Benkler (2006) have pointed out problems in online deliberation. Sunstein (2001) has warned how the Internet will not sustain but rather, fragment a public sphere by providing a chamber that echoes polarization among those in that realm. Benkler (2006) is in accord with the critique of Habermas that suggests commercial mass mediated public discussion is at the level of the "lowest common denominator" and lacks a sense of upholding the public good. The commercially run blogs of the Ni-Channel may create a combination of both, but at the same time provide a channel that resembles a trustworthy, objective source of political information. Benkler also has commented on how the 
Internet lacked the strength to uphold a Jeffersonian model of democracy due to the polarizing views of the users. This weakness may not imply that the Internet is lacking in influencing people who access information. The current Matome Saito aggregators may relate to the findings of Yoo (2011), that has stated gatekeepers who do not produce original content can be as influential as the traditional elite media and that the news found in the aggregator's agenda were in sync with the public agenda, suggesting it to have some significant influence over people. Kashiwabara (2012) also probed how the Ni-Channel and Matome Saito may act as a double gatekeeper when providing information to a wider audience. Aggregators may function as gatekeepers of information, as the legacy media have acted in the past. Williams and Delli Carpini (2000) consider the Internet to have no gates, so there is no such thing as gatekeeping. However, Hindman (2009) claims that there is gatekeeping done through aggregation and that the Internet supports the filtering of the political information. I will now examine how a variation of gatekeeping may be occurring in the Japanese context through reviewing a survey result that probes the Matome Saito.

\section{How are Matome Saito Aggregators used among Japanese}

The social media lab of Dentsu Public Relations (the largest media public relations corporation in Japan) named Antenna conducted a survey about Matome Saito in June 2012 (random sampled $\mathrm{n}=10,000$, male $=4,359$ and female $=5641$, age 15 or older, nationwide). Among the 10,000 respondents, $36.5 \%$ (male $=43.2 \%$, female $=31.4 \%$ ) had experience of using or viewing Matome Saito.

Among 1200 Matome Saito users (male=600, female=600), 76.2\% were using Matome Saito more than once a week, and $18.5 \%$ were heavy users (in other words, these respondents were using Matome Saito multiple times per day). Over 30\% of the male respondents in their teens and twenties, and females in the age range of twenties were heavy users of Matome Saito. $90 \%$ of male respondents in the age range of twenties used Matome Saito over once a week. Among males in the age range of 50 s and 60 s, approximately $10 \%$ were heavy users and over $70 \%$ viewed the Matome Saito more than once a week. $45 \%$ of Matome Saito users indicated they have seen information initially on Matome Saito later being broadcast on television. $14.6 \%$ of respondents claim they have had this experience numerous times.

The top reason why respondents use or view Matome Saito was to "kill time" (48.2\%), followed by the evaluation that "information is well summarized and easy to view" $(38.5 \%)$, and that they "can access a wider variety of information than mass media" (38.2\%). Among the respondents in their teens and twenties, the second most common reason was because it is "fun" and among respondents in their 50s and 60s, the second most common reason was because they "can access a wider variety of information than mass media." Therefore, the Matome Saito were being considered a form of entertainment among younger users, and as complementary channels of news for older users in their $50 \mathrm{~s}$ and $60 \mathrm{~s}$. The younger respondents had a tendency to view Matome Saito during transportation (commuting), eating or when in restrooms. One can infer that the Matome Saito were being used in brief moments of spare time to browse information.

One explanation for this may be that many Matome Saito aggregators are also optimized as smartphone applications such as 2Ch Matome, 2ChMX or MT2. These applications that can be used on smartphones (multiple platforms) and tablets (multiple platforms) are available as freeware and essentially provide the same information because the logic used for aggregation on these applications is identical.

When a smartphone application user views the content on these aggregator applications, he/she can view both a list of 1) newly arrived edited thread blog titles and 2) popular edited thread blog titles of the day. The user can click the thread that seems most interesting and then view the actual linked Matome Saito thread. When one views the titles of the threads, one will quickly notice that many titles have multiple consecutive letters of " $w$ " after them, which are the equivalent of "lol" because " $w$ " refers to the Japanese word warai or laugh. The term omoshiroi in Japanese used to explain "interesting", also has the meaning "fun" and may mean both in certain contexts. These 
threads are usually ones that fall into the category of "material" that has gone through a "festival" of flaming. The edited threads usually provide a cleaned up insight into what people (users of $\mathrm{Ni}$ channel) think/thought about this particular issue. The user can check to see if their opinion is the same with the majority of entries of the edited blogs, and he/she can also view how their opinion is viewed among others if they are able to find comments towards someone with the same opinion. Many Matome Saito aggregator users do not view the Ni-channel forum, and rarely check the actual source, if ever, so the aggregated information source becomes their sole source and may become the source of conversation topics among friends that may or may not use the aggregators.

At times, the Matome Saito language is a condensed version of the exchanges found in the entries of threads in the Ni-Channel bulletin board among those considered to be Net-uyoku. They are often using belligerent language towards the mainstream media, as they claim the liberal media to be opposing the Liberal Democratic Party, however, this may be a reflection of their jealousy towards the affluence of those working in the media industry. The Net-uyoku continuously post on the Ni-channel that the "liberal" media have sold out their country and that they are unhappy about the way the media attack the Liberal Democratic Party. They argue the attacks against the Liberal Democratic Party are a reflection of the loyalty of the media to other governments such as South Korea. Their arguments are against the individuals and groups that oppose the Liberal Democratic Party and their ideology is aligned to the main conservative politicians in the Liberal Democratic Party. The fall and rise of the Liberal Democratic Party has been one of major interest to the Netuyoku, Ni-channel and Matome Saito, and during the December 2012 House of Representatives Election in Japan, the Matome Saito may have been an effective information source for those with less familiarity of Japanese politics and issues.

\section{The December 2012 House of Representatives Election in Japan}

In the past, Japan had often been labeled as an uncommon democracy (Tsujinaka, 2010), or one without competition (Scheiner, 2005), although these ideas were during the time when the Liberal Democratic Party was dominant for several decades after World War II. Their political system that was set up in 1955 after World War II and remained in power until 1993. After their fall in 1993 and rise again to power, dominance was evident again under the popular former Prime Minister Junichiro Koizumi, until their fall again in 2009. After the landslide defeat in 2009, the Liberal Democratic Party had to maneuver in a way to overcome the Democratic Party of Japan and the other numerous newer parties, such as the People's Life First Party (founder: Ichiro Ozawa) which was built by combining the Tomorrow Party of Japan, Nuclear-Free Party and Green Wind, and the Japan Restoration Party (founders: Tōru Hashimoto and Shintaro Ishihara). After 2009, many Liberal Democratic party members joined other parties or formed new ones such as Your Party, the New Renaissance Party and the Sunrise Party. This situation of politicians scrambling towards newer political factions was very similar to the period between 1992-1993 when Morihiro Hosokawa left the Liberal Democratic Party and a no-confidence vote against Miyazawa was passed. At that time, more than 50 Liberal Democratic Party members left and formed other parties such as New Party Sakigake and Shinseito.

In November 2012, after Yoshihiko Noda, the former Democratic Party of Japan prime-minister announced the dissolving of the government and the lower house election to be held in December 2012, 1504 candidates ran. Even with the largest number of candidates with the current system, numerous polls indicated that around 40 per cent of Japanese were undecided. On December 16, 2012 the results came in, with a landslide victory for the Liberal Democratic Party, gaining 294 seats with $16,623,542$ total votes. The second popular party was the Japan Restoration Party with $12,262,144$ votes but third in seats with 54 . The third popular party was the ruling DPJ (at the time) with 57 seats but third in popularity with 9,628,483 votes. The New Komeito Party came in fourth with 31 seats and 7,116,265 votes, followed by Your Party with 18 seats and 5,245,586 votes. The Tomorrow Party of Japan gained 9 seats with 3,424,071 votes and the Communist Party with 8 seats and 3,689,988 votes. The Social Democrats ended with 2 seats, The People's New Party and New Party Daichi both ended with 1 seat (faction dissolved with only 1 seat), and 5 seats to 
independents (Total 480 seats). The landslide victory by the Liberal Democratic Party was considered a surprise by the mainstream media, and this study is aimed at probing into what kind of other information flows in cyberspace may have been occurring at the time of the 2012 election by investigating the content of the Matome Saito aggregators.

\section{Content Analysis of Matome Saito Aggregators from November to December 2012}

In this study, I examine the content of Matome Saito to test Hypotheses 1 and 2 because the Matome Saito may have been vital information sources that provide concisely edited news commentary on various political news topics in relation to the December 2012 House of Representatives Election in Japan. The political news on Matome Saito have been observed to be sympathetic to the Liberal Democratic Party due to the process of information being posted by the Net-uyoku onto the Ni-channel being further condensed by the blogs of the Matome Saito. The blogs of threads about other parties such as the Democratic Party of Japan and Restoration Party that are positioned more on the left and right of the political spectrum can be assumed to be less supportive due to the fact that the Democratic Party of Japan is viewed to be liberal and the Japan Restoration Party to be aligned to the media due to the former leader at the time of Töru Hashimoto being a former television celebrity lawyer. All parties other than the Liberal Democratic Party fall outside the preference of the Net-uyoku definition of Tsuji (2008).

This paper examines the tone of argument in the Japanese Matome Saito aggregators in relation to political issues preceding the December 2012 Japanese General Election, after the Prime Minister at that time, Noda dissolved the parliament. The time period selected was from November 16, 2012 immediately after dissolving of government until December 20, 2012 when evaluation of the election results started to decrease five days after the election.

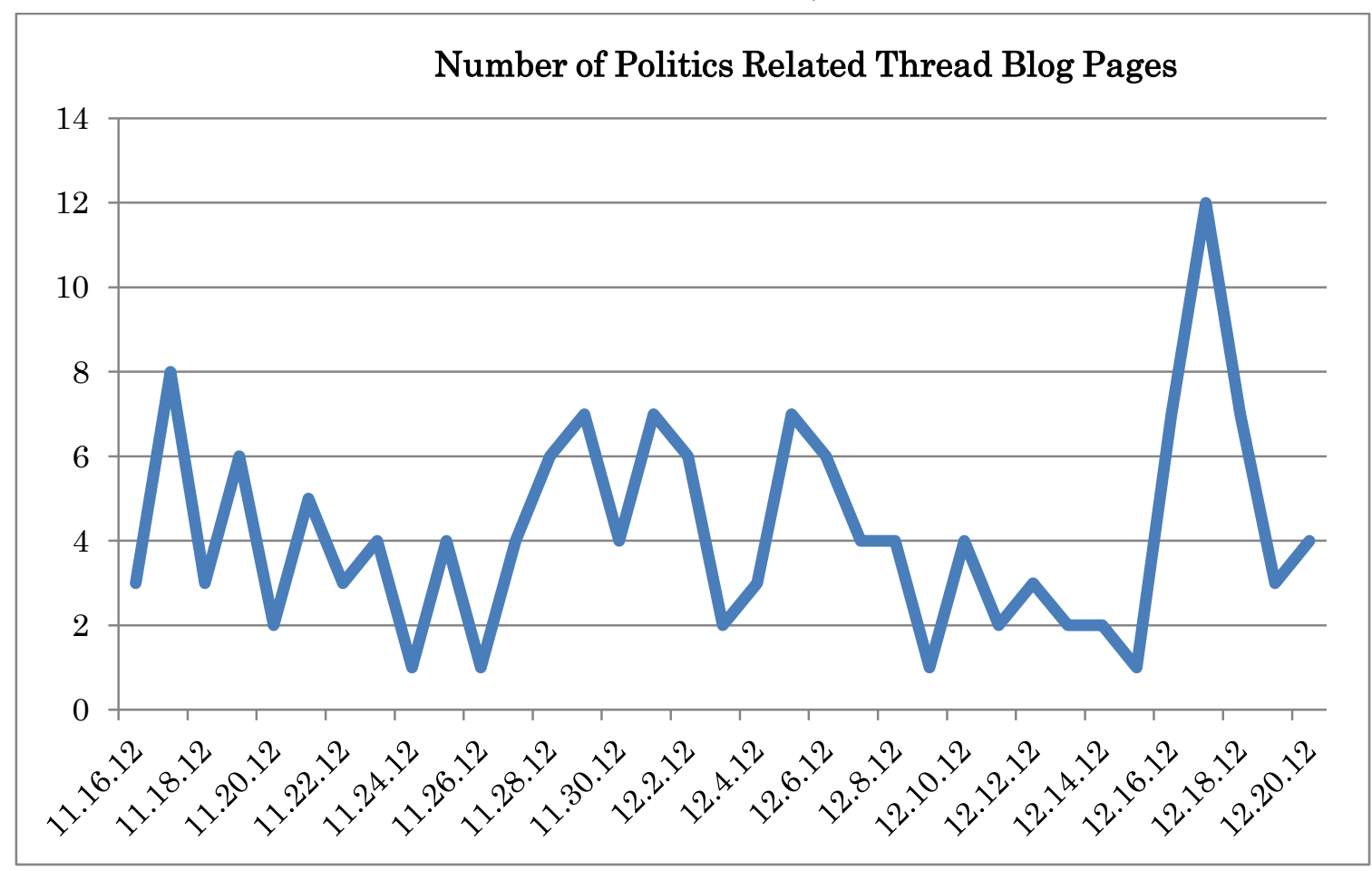

Figure 2. The Number of Politics Related Titles during Nov. $16 \sim$ Dec. 20, 2012 on MT2

During the time span of 35 days of this analysis, the top 50 daily thread blog pages of the Matome Saito aggregators from each day were selected. The reason for selecting these 50 blog pages is because they are the first 50 titles of aggregated information optimized for smartphones. These are the blogs that are most viewed by all the users of Matome Saito aggregator applications. 
Methodology: A total of 1750 Matome Saito blog pages from November 162012 - December 20, 2012 were analyzed. Each thread blog is a summary of one Ni-Channel thread that is composed of 1000 entries and recomposed into a blog page.

1) Three coders a) male=21, b) male=22, c) female=23, all three college students in their senior year classified the 1750 Matome Saito blogs into politically related blogs and nonpolitical blogs. The politically related blogs were classified to be political a) if they have any proper nouns or $b$ ) other language in the title or content that related to i) political parties or ii) politicians, iii) political characteristics, iv) political issues, and v) diplomatic relations with Japan.

2) Figure 2 indicates the number of politically related edited thread blog pages for each day during the period of analysis of November 16 until December 20, 2012 from the top 50 thread titles of the Matome Saito out of the total of 1750 blogs. The number of thread blog pages related to politics was 148 in total (view appendix). The coders were in $100 \%$ agreement of which blog pages were political and non-political. One can observe a sharp increase in the number of thread blogs from December 16 through 18, 2012, immediately after the House of Representatives election that was held on December 16.

3) To investigate the details and context of each thread blog, three coders (male=2 (age 21, 22), female=1 (age 23), nationality Japanese=3) coded each thread by determining the subject matter (i.e. LDP, DPJ, China, Mass Media) and the discussion material (1. Negative, 2. Positive, 3. Flaming against the initial article). The content analysis was conducted during January 21, 2013 - February 1, 2013 with daily consultation with the primary researcher.

- Subject Matter: Subject matter was determined by the most common proper noun that appeared in each thread blog.

- The evaluation of the discussion material was determined by the following:

1. Negative Classification: language or cipher like language (Japanese word that is improperly encoded in the entry but that can be read phonetically or by other interpretation to mean another word) that can be interpreted to be opposing to the subject matter. Opposing $=$ consisting of disagreement or negative evaluation (such as adjectives) of the subject matter.

2. Positive Classification: language or cipher like language that can be interpreted to be supportive (such as adjectives) of the subject matter. Supportive = consisting of support or backing up of the subject matter.

3. Classification as Flaming: language or cipher like language that can be interpreted to be hostile (such as adjectives) of the subject matter.

Hostile = consisting of cursing, derogatory, insulting language towards the subject matter

4. Other

- Each thread blog was analyzed by counting the number of entries that were 1. Negative, 2. Positive, 3. Flaming 4. Other, and the thread blogs were classified into one of the three evaluations of 1 . Negative, 2. Positive, 3. Flaming (none of the 148 blog pages were dominantly "other").

- The inter-coder reliability of the evaluations was (Krippendorff) $\alpha=.930$ and when the 148 political thread blogs were classified into one of the three dominant evaluations, the inter-coder agreement was at $100 \%$. In order to avoid any contradictions or misinterpretation of evaluation, simultaneous consultation during the analysis was conducted daily to examine any disputable coding results. 
5. Text analysis software was also used to evaluate the $1750 \mathrm{blogs}$, however, the prevalence of cipher-like language and complexity due to the variance of the language that changes according to the context, made analysis complicated and the results inconclusive.

Table 1 summarizes the content analysis result. Among the 148 thread blogs, the Liberal Democratic Party was the most popular subject with 44 thread blog pages, followed by the Democratic Party of Japan with 31 thread blog pages. The Japan Restoration Party was third with 13 thread blog pages.

Table 1. Subject and Discussion context of Thread Blogs Nov. 16 - Dec. 20, 2012

\begin{tabular}{|l|r|r|r|r|}
\hline \multirow{2}{*}{ Subject Matter } & \multicolumn{2}{|c|}{ Classification of Blog Page } & \multirow{2}{*}{ Total } \\
\cline { 2 - 4 } China (nation) & Negative & Flamed & Positive & \\
China/South Korea (nations) & 7 & 0 & 0 & 7 \\
Democratic Party of Japan (political & 2 & 0 & 0 & 2 \\
party) & 31 & 0 & 0 & 31 \\
Happiness Realization (political party) & 0 & 0 & 1 & 1 \\
Netizens, SNS (related to users) & 0 & 0 & 4 & 4 \\
New Komei Party (political party) & 3 & 0 & 0 & 3 \\
South Korea (nation) & 5 & 0 & 0 & 6 \\
Liberal Democratic Party (political party) & 2 & 12 & 30 & 44 \\
Mass Media (institution) & 8 & 1 & 1 & 10 \\
Other (miscellaneous) & 8 & 3 & 2 & 13 \\
Philippines (nation) & 0 & 0 & 1 & 1 \\
Restoration Party (political party) & 13 & 0 & 0 & 13 \\
Russia (nation) & 3 & 0 & 0 & 3 \\
Switzerland (nation) & 0 & 0 & 1 & 1 \\
Tomorrow Party (political party) & 7 & 0 & 0 & 7 \\
United States (nation) & 0 & 0 & 1 & 1 \\
Your Party (political party) & 16 & 42 & 148 \\
Total & & 0 & \\
\hline
\end{tabular}

By further analysis of the threads, the Liberal Democratic Party had the most dominantly positive discussions/entries/comments, with 30 thread blog pages that were dominantly positive of the Liberal Democratic Party. In contrast, the Democratic Party of Japan had the most discussions that were dominantly negative with all blog pages having dominantly negative evaluations or discussions of the Democratic Party of Japan. The Japan Restoration Party had the second most dominantly negative discussions, with all blog pages dominantly being negative evaluations or discussions. The content analysis results also indicated that 12 negative blogs of news articles about the Liberal Democratic Party were dominantly flamed against and had a majority of comments or entries supporting the Liberal Democratic Party. In other words, 42 thread blog pages, or more than a quarter of the total political blog pages found in the duration were dominantly 
supportive of the Liberal Democratic Party. Only two thread blog pages out of the 44 threads were negative threads of the LDP. Most thread blogs of the other political parties were also negative, such as those related to the Tomorrow Party of Japan ( 7 negative threads), New Komei Party (3 negative threads), and Your Party (1 negative and 1 positive).

Among the discussions of other nations, China had 7 negative thread blog pages, South Korea had 5 negative thread blog pages, China and South Korea shared 2 negative thread blog pages, Russia had 3 three negative thread blog pages, the U.S., the Philippines, and Switzerland each had 1 positive thread blog page. The mass media had 8 dominantly negative thread blog pages, 1 thread of flaming and 1 positive thread blog page. The thread blog pages of netizens or social media were all dominantly positive (4 blogs).

\section{Discussion - Construction of the Political Right Wing in Japan?}

The Matome Saito are edited popular topic threads of the Ni-Channel anonymous bulletin board. The information on the Matome Saito is efficiently and concisely edited for those who do not usually access the vast Ni-Channel forum. The Matome Saito aggregators and the smartphone/tablet apps provide a convenient tool for those who want to access various information, including politics - especially for those who are not traditionally knowledgeable about politics. The Matome Saito also create many potential problems in this process because the information on Matome Saito are not always balanced, and are sometimes heavily inclined towards to the skewed political views of those managing these sites and the entries of the Net-uyoku on NiChannel that are the main information source. This paper overviews the condensation mechanism of the information flow of Net-uyoku entries in the Ni-Channel messaging forum of Japan that are edited into summary blogs of Ni-Channel called Matome Saito, and the aggregation of the numerous Matome Saito, with a focus on Japan and the December 2012 election. I examined the tone argument of the Matome Saito aggregation by conducting a content analysis of 1750 blog pages summarizing threads from November 16, 2012 to December 20, 2012 spanning the time period following the dissolving of the Japanese government by Prime Minister Noda to five days after the election inclusive. The analysis found 148 politically related thread blog pages and further analyzed the content of each page to examine the following hypotheses and research questions.

H1: The top political news topics on Matome Saito use supportive language in relation to the Liberal Democratic Party of Japan.

H2: The top political news topics on Matome Saito use opposing language in relation to political parties other than the Liberal Democratic Party of Japan.

$\mathrm{RQ}$ : What climate of opinion are the top political news Matome Saito blog pages creating during the time of the Japanese General Election of the House of Representative in 2012?

This study found Hypotheses 1 and 2 to be supported by the content analysis results, and that the climate of opinion of the Matome Saito were found to be in agreement with Tsuji's (2008) operational definition of Net-uyoku traits, however, the right-wing tone arguments were found to be further "condensed" by aggregation. The following blog pages for the duration of this study illustrate the tone of argument in agreement with Net-uyoku ideology (view Appendix for full list of titles of blog pages):

I. Net-uyoku tone of argument: The DPJ and media are closely tied they have betrayed the Japanese people (November 16: "Double Crossed by the DPJ. Swindled by the media. We mustn't forgive"; December 1: "Why are Japanese news media politically biased and not neutral?")

II. Net-uyoku tone of argument: The media are negative about the Liberal Democratic Party (November 18: "TBS captions footage of Abe with news about a news anchor getting arrested for public obscenity"; December 19: Shukan Asahi (weekly magazine) cover page of Abe is horrible.) 
III. $\quad$ Net-uyoku tone of argument: The LDP are supportive of revising Article 9 (November 21: "LDP manifesto, YES! Revise Article 9, Establish the Dept. of Defense, Income increase of 50 trillion yen.")

IV. Net-uyoku tone of argument: South Korea is against the LDP (November 22: South Korea, "LDP is a far right wing party now. Don't vote for them.")

V. Net-uyoku tone of argument: The DPJ is aligned with other (unfriendly) nations (November 21: Pro-Chinese DPJ MP Okada, "Abe should watch his mouth unless he is intending to be in the opposition camp forever"; December 2: MP Doi former DPJ, "I have always served for South Korea.")

Through the content analysis, this study can suggest in the period encompassing the 2012 lower house election in Japan, the social and political views found in the top Matome Saito aggregator blog pages were almost totally supportive of the Liberal Democratic Party and generally negative of most other political parties in Japan. They were mostly negative of the then ruling Democratic Party of Japan. Any news article critical of the Liberal Democratic Party was flooded with flaming. On the other hand, one must not overlook that the content analysis also indicates that the Japan Restoration Party (far right wing political party) was also summarized negatively by the entries in the pages, suggesting the far right wing policies of the Japan Restoration Party were not supported by the Ni-Channel, nor the Matome Saito managers, most probably due to the leader Hashimoto being a former television celebrity lawyer. This study also anticipated the results to show that the Matome Saito aggregated threads reflect the voice of Net-uyoku, and simultaneously appear more empathetic to the ultra right wing politicians of the Japan Restoration Party (Mie, 2013). However, the analysis results show that there seem to be some discrepancies of this perception when analyzed. This is a discrepancy found between the real ultra-nationalistic organizations and the voices of the Net-uyoku reflected in the analyzed pages.

To define what is nationalistic in a Japanese context is difficult, however, one can suggest that the analyzed pages in this study are in agreement with the tone of argument of the Net-uyoku. The arguments in the analyzed pages have a pro-military expansion, pro-aggressive policy towards bordering nations and may be pushing for a "right-wing" policy, although there are negative discussions of far-right wing parties, such as those negative entries related to the Japan Restoration Party, there are also friendly comments towards neighboring areas such as the Philippines and Taiwan (view Appendix). As being negative of liberal and conservative policies alike and voicing amity towards a few select bordering nations, the Matome Saito may look like they are balanced and neutral. One may suggest that those less informed or unaware of Japanese political contexts may believe that the Matome Saito are providing their readers a "moderate" political view, and that the "moderate" party Japan is the Liberal Democratic Party. The flaming found against the critical articles towards the Liberal Democratic Party in this analysis may further create this perception, as the Matome Saito are edited in a way that they are highly negative of the far right wing Japan Restoration Party. One can suggest that this may be a form of a deception, however, these claims requires further verification and evidence through future research.

As a limitation, this study did not conduct a survey among Matome Saito aggregator users in relation to their usage of those, and their political preference and voting behavior. Still, even with these limitations, this study provides an insight into the content of the Matome Saito aggregators and suggests how this content and information flow may have contributed to the real discussions concerning politics leading to the December 2012 lower house election.

Future studies that conduct surveys among Matome Saito aggregator users and especially smartphone/tablet app users need to determine how they are contributing to the perception of public opinion in Japan, especially among those that are using the legacy mass media less frequently. Metrics and big data related to access of this data is important and may provide information on the general trend, however, fine details may be overlooked. Therefore, researchers need to comb through such data in order to find discoveries that may be lost in quantification. 
The popularity of Matome Saito as an information source has been verified in this study, and in a positive light, they are allowing many Internet users to conveniently receive common information and political viewpoints via a "meso" medium among popular topics through smartphone apps that provide the information on these sites tailored for optimum results on these devices. They are creating interest in politics among the youth that use this medium for news and information. Most of the thread titles are sensational, as the Matome Saito managers need to create revenue by having as many viewers to their blogs as possible, so the current flow of information may seem alarming but the actual effects on the general public of Japan of such, sometimes xenophobic and aggressive arguments in these threads need further research.

\section{References}

Benkler, Y. (2006). The Wealth of Networks: How Social Production Transforms Markets and Freedom. New Haven, CT: Yale University Press.

Chaffee, S. H., \& Metzger, M. J. (2001). The end of mass communication? Mass Communication and Society, 4(4), 365379.

Coleman, R. \& McCombs, M. E. (2007). The Young and Agenda-Less? Exploring Age-Related Differences in Agenda Setting on the Youngest Generation, Baby Boomers, and the Civic Generation. Journalism \& Mass Communication Quarterly, 84(3), 495-508.

Deuze, M. (2003) The Web and its Journalisms: Considering the Consequences of Different Types of Newsmedia Online, New Media and Society 5 (2), 203-230.

Dentsu Public Relations (July 18, 2012). Houdou Shiryo: Atarashi Jyohou Ryutsu Kouzou - Himatsubushi Media "Matome Saito" no Riyou Jittai Chousa. [Press Release: New Information Distribution Structure: Media to Kill Time "Matome Saito" Usage Survey] http://www.dentsu-pr.co.jp/wp-content/themes/dpr themes/release/20120718 report.pdf

Fackler, M. (2010, August 28). New Dissent in Japn is Loudly Anti-Foreign. New York Times. http://www.nytimes.com/2010/08/29/world/asia/29japan.html?pagewanted=all\& $r=0$

Hindman, M. (2009). The myth of digital democracy. Princeton, NJ: Princeton University Press.

Jennings, M. K., and Zeitner, V. (2003). Internet Use and Civic Engagement: A Longitudinal Analysis. Public Opinion Quarterly 67, 311-34.

Johnston, E. (2006, March 14). Net boards venue for faceless rightists. Japan Times. http://www.japantimes.co.jp/news/2006/03/14/news/net-boards-venue-for-faceless-rightists/\#.Ui1gObxPpkA

Kaigo, M. \& Watanabe, I. (2007). Ethos in Chaos? Reaction to Video Files Depicting Socially Harmful Images in the Channel 2 Japanese Internet Forum. Journal of Computer-Mediated Communication, 12(4), 1248-1268.

Kashiwabara, T. (2012). "A consideration of news communication by "2-channel thread editing blog" Mita Tetsugakkai No.128 (2012. 3) , 207- 234.

Kreuger , B. S. (2002). Assessing the Impact of Intemet Political Participation in the United States: A Resource Approach." American Political Research 30, 476-98.

Mie, A. (2013, January 8). Xenophobia finds fertile soil in web anonymity. The Japan Times. http://www.japantimes.co.jp/news/2013/01/08/reference/xenophobia-finds-fertile-soil-in-webanonymity/\#.Ui1atLxPpkA

Onishi, N. (2004, May 9). Japanese find a forum to vent most-secret feelings. The New York Times. http://query.nytimes.com/gst/fullpage.html?sec=technology\&res=9F01E5DE153CF93AA35756C0A9629C8B63

Prior, M. 2007. Post-Broadcast Democracy. New York: Cambridge University Press.

Scheiner, E. (2005). Democracy without Competition in Japan: Opposition Failure in a One-Party Dominant State. Cambridge: Cambridge University Press.

Sunstein, C. (2001). Republic.com. Princeton, NJ: Princeton University Press.

Tolbert, C. J., \& McNeal, R. S. (2003). Unraveling the Effects of the Internet on Political Participation? Political Research Quarterly 56, 175-85.

Tsuji, D. (2008). Intanetto ni okeru "ukeika" gennshoni kannsuru jisshokenkyuchousakekka gaiyo houkokusho [A report and summary on an empirical study on the right wing tendencies in the Internet] Osaka University.

http://www.d-tsuji.com/paper/r04/report04.pdf 
Tsujinaka, Y. (2010). Japan Report, Uncommon Democracies Revisited: Loss of One-Party Dominance, Causes, and Consequences (Conference paper at University of Tsukuba, March 18, 2010).

Tsuda, D. (2009). Twitter Shakairon Aratana Real Time Webno Choryu [Twitter Social Theory - A New Real Time Web Tide] Tokyo: Yousensha.

Williams, B.A. \& Delli Carpini, M. X. (2000). Unchained Reaction: The Collapse of Media Gatekeeping and the ClintonLewinsky Scandal. Journalism 1: 61-85.

Williams, B.A. \& Delli Carpini, M. X. (2004). Monica and Bill All the Time and Everywhere. The Collapse of Gatekeeping and Agenda Setting in the New Media Environment. American Behavioral Scientist,47(9),1208-1230

Yoo, Sung Woo. Google and Yahoo as the Next Gatekeeper: Examining Agenda Setting Effects of News Aggregators. Paper presented at the annual meeting of the International Communication Association, TBA, Boston, MA, May 25 $2011<$ Not Available>. 2012-06-18 http://www.allacademic.com/meta/p492217 index.html 
Appendix. The 148 political thread blog page titles from November 16 - December 20, 2012, translated from Japanese into English.

\begin{tabular}{|c|c|c|}
\hline Date & \begin{tabular}{|l} 
Daily \\
rank
\end{tabular} & Title of Thread \\
\hline $2012 / 11 / 16$ & 31 & Double-crossed by the DPJ. Swindled by the media. We mustn't forgive them. \\
\hline $2012 / 11 / 16$ & 39 & Japan Restoration Party takes 1 million yen from each candidate as PR expense \\
\hline $2012 / 11 / 16$ & 50 & DPJ "Please don't leave us :( " MPs leaving DPJ "Good luck, DPJ" \\
\hline $2012 / 11 / 17$ & 1 & MPs pictures leaving DPJ, resemble pornographic drama scene. \\
\hline $2012 / 11 / 17$ & 15 & Abe "We must teach parents not to name their kids with silly names" (ie. Pikachu) \\
\hline $2012 / 11 / 17$ & 17 & Abe "Japan must stop self-torture over history! The citizens must know the truth. \\
\hline $2012 / 11 / 17$ & 26 & DPJ Hosono "The LDP is full of 2nd generation politicians. Worse than communist nations." \\
\hline $2012 / 11 / 17$ & 35 & (Same as item 17, but from a different blog.) \\
\hline $2012 / 11 / 17$ & 37 & $\begin{array}{l}\text { South Koreans fear Abe! All lies will be corrected and Koreans in Japan will have nowhere to } \\
\text { go. }\end{array}$ \\
\hline $2012 / 11 / 17$ & 40 & $\begin{array}{l}\text { Nobuo Ikeda "Everyone around Abe is clueless about economics. Noda is still better, so vote } \\
\text { for him." }\end{array}$ \\
\hline $2012 / 11 / 17$ & 44 & Comedian says that Abe is the one that quit his job like a chicken. \\
\hline $2012 / 11 / 18$ & & $\begin{array}{l}\text { Son of Chinese Communist Party leader drives a Ferrari butt naked and into the wall. } \\
\text { Censored "Ferrari" in Chinese Net. }\end{array}$ \\
\hline $2012 / 11 / 18$ & 32 & $\begin{array}{l}\text { TBS captions footage of Abe with news about a news anchor getting arrested for public } \\
\text { obscenity. }\end{array}$ \\
\hline $2012 / 11 / 18$ & 38 & $\begin{array}{l}\text { DPJ prefectural union "The negative legacy of the LDP was too big to negate during the past } \\
\text { three years." }\end{array}$ \\
\hline $2012 / 11 / 19$ & 9 & $\begin{array}{l}\text { LDP to change Livelihood Protection Law. Those on welfare will receive food and clothing, not } \\
\text { cash. }\end{array}$ \\
\hline $2012 / 11 / 19$ & 13 & K. Sugiyama claims that TBS is altering Abe's low tone word to make it difficult to hear. \\
\hline $2012 / 11 / 19$ & 27 & $\begin{array}{l}\text { MP Renho of DPJ - "Vote for me! I did the sorting out of wasteful govt. spending. I have } \\
\text { experience!" }\end{array}$ \\
\hline $2012 / 11 / 19$ & 30 & What will happen if the LDP wins and wins back the government? \\
\hline $2012 / 11 / 19$ & 31 & $\begin{array}{l}\text { Abe "Bank of Japan will swallow the government bonds for rebuilding." Hedge funds: "We're } \\
\text { going to die! LOL!" }\end{array}$ \\
\hline $2012 / 11 / 19$ & 36 & $\begin{array}{l}\text { Government related banker claims, "Shizuka Kamei called us to lend him money to build new } \\
\text { Anti TPP party." }\end{array}$ \\
\hline $2012 / 11 / 20$ & 13 & Former PM Hatoyama is not going to run for the House of Representatives Election \\
\hline $2012 / 11 / 20$ & 44 & $\begin{array}{l}\text { South Korea "Chinese and Japanese are trash because they keep lying about history. } \\
\text { Shameful." }\end{array}$ \\
\hline $2012 / 11 / 21$ & 10 & Yen is lower thanks to Abe. DPJ Yen barrier of 82 yen to US $\$$ has been broken. \\
\hline $2012 / 11 / 21$ & 24 & DPJ PM Noda being considered for expulsion from DPJ. LOL! \\
\hline $2012 / 11 / 21$ & 29 & Happiness Realization Party - rock solid platform. So scary it sends shivers down the spine. \\
\hline $2012 / 11 / 21$ & 32 & $\begin{array}{l}\text { LDP manifesto. YES! Revise Article 9. Establish the Dept. of Defense. Income increase of } 50 \\
\text { trillion yen. }\end{array}$ \\
\hline $2012 / 11 / 21$ & 36 & $\begin{array}{l}\text { Pro-Chinese DPJ MP Okada "Abe should watch his mouth unless he is intending to be in the } \\
\text { opposition camp forever." }\end{array}$ \\
\hline $2012 / 11 / 22$ & & $\begin{array}{l}\text { LDP to change elementary school to } 7 \text { years. Mandatory education to } 10 \text { years. Public } \\
\text { Commitment. }\end{array}$ \\
\hline
\end{tabular}




\begin{tabular}{|c|c|c|}
\hline $2012 / 11 / 22$ & 26 & LDP public commitment for regulating animation and manga for promoting wholesome youth. \\
\hline $2012 / 11 / 22$ & 36 & South Korea, "LDP is a far right wing party now. Don't vote for them." \\
\hline $2012 / 11 / 23$ & 31 & South Korea, "Don't vote for LDP. All those who love South Korea should rise." \\
\hline $2012 / 11 / 23$ & 32 & LDP manifesto YES! Clearly states against Koreans in Japan to receive voting rights. \\
\hline 2012/11/23 & 36 & LDP food coupons for those on welfare YES!!!!! \\
\hline $2012 / 11 / 23$ & 45 & $\begin{array}{l}\text { US Expert "Great depression in South Korea, stocks will tumble to half, Seoul will be flooded } \\
\text { with bankruptcy and riots." }\end{array}$ \\
\hline $2012 / 11 / 24$ & 31 & $\begin{array}{l}\text { Hashimoto "LDP not able to resist Takeshima being occupied. Dept. of Defense is } \\
\text { distraction." }\end{array}$ \\
\hline $2012 / 11 / 25$ & 2 & $\begin{array}{l}\text { PM Noda debates with LDP Abe. Noda "Only those who own stocks and land will greet } \\
\text { inflation, not ordinary folk." }\end{array}$ \\
\hline $2012 / 11 / 25$ & 34 & $\begin{array}{l}\text { PM Noda "Let's have a Q\&A session." Abe "If it is on Nico Nico Live, then ok." Abe is our } \\
\text { next PM. }\end{array}$ \\
\hline $2012 / 11 / 25$ & 43 & Diet minutes "After we allowed small children, illegal alien stowaways increased suddenly." \\
\hline $2012 / 11 / 25$ & 45 & $\begin{array}{l}\text { Former PM Shigeru Yoshida sent a petition to Gen MacArthur to send Koreans in Japan back } \\
\text { to Korea. }\end{array}$ \\
\hline $2012 / 11 / 26$ & 34 & $\begin{array}{l}\text { Nico Nico Douga protests against DPJ "Calling us a biased video site is a vilification without } \\
\text { any grounds." }\end{array}$ \\
\hline $2012 / 11 / 27$ & 4 & $\begin{array}{l}\text { South Korea "Not having BIGBANG or 2PM on the New Year's Eve Singing Contest is absurd. } \\
\text { Don't mix politics with culture. Japanese are so evasive" }\end{array}$ \\
\hline $2012 / 11 / 27$ & 20 & Minster of Education Makiko Tanaka "Mr. Abe doesn't know much about economics." \\
\hline 2012/11/27 & 29 & DPJ Okada "Japan will no longer have economic growth." Say What? \\
\hline $2012 / 11 / 27$ & 41 & Russian magazine "Return northern islands and create an alliance with Japan." \\
\hline $2012 / 11 / 28$ & 4 & $\begin{array}{l}\text { Economist claims that TV Asahi news program tried to force him to mention hyper-inflation } \\
\text { with financial bankruptcy but refused. }\end{array}$ \\
\hline $2012 / 11 / 28$ & 16 & (Same as item 4 , but from a different blog.) \\
\hline $2012 / 11 / 28$ & 28 & $\begin{array}{l}\text { Tomorrow Party's Kada on a Morning TV program. She was a total mess. Was talking } \\
\text { nonsense to the whole world. }\end{array}$ \\
\hline 2012/11/28 & 37 & (Same as item 4 and 16 from 2012/11/28, but from a different blog.) \\
\hline $2012 / 11 / 28$ & 44 & $\begin{array}{l}\text { Chinese and South Koreans shocked. John Lennon paid respects to Yasukuni Shrine when } \\
\text { alive. }\end{array}$ \\
\hline $2012 / 11 / 28$ & 46 & Your Party public commitment lol. $4 \%$ growth, income will increase by $50 \%$. \\
\hline $2012 / 11 / 29$ & 10 & Nico Nico Live Political Debate broadcast. Dwango wins. \\
\hline 2012/11/29 & 15 & Restoration Party public commitment: Abolish minimum wage, lax laws on layoffs. Seriously? \\
\hline $2012 / 11 / 29$ & 26 & Tokyo mayor candidate Inose's poster is really horrible. \\
\hline $2012 / 11 / 29$ & 31 & $\begin{array}{l}\text { [Nutcase] Eriko Fukuda "I will run from the Tomorrow Party but will leave after getting elected, } \\
\text { because it is easier to elected through that party. }\end{array}$ \\
\hline $2012 / 11 / 29$ & 37 & $\begin{array}{l}\text { Comedian says, "Politicians should be more serious about choosing PM. Why couldn't you } \\
\text { find out if the person can't read properly." }\end{array}$ \\
\hline $2012 / 11 / 29$ & 41 & 2009 LDP TV commercial predicts the current LDP. Now gaining much attention. \\
\hline $2012 / 11 / 29$ & 44 & (Same as item 31, but from a different blog.) \\
\hline $2012 / 11 / 30$ & & $\begin{array}{l}\text { Toru Hashimoto "Abolish minimum wage and the country will support those who can't live on } \\
\text { that pay." }\end{array}$ \\
\hline
\end{tabular}




\begin{tabular}{|c|c|c|}
\hline $2012 / 11 / 30$ & 5 & China "Hawaii is probably our territory." US Sec. of State reveals talks with China \\
\hline $2012 / 11 / 30$ & 14 & $\begin{array}{l}\text { Restoration Party public commitment. Asahi "What is this?" Sankei "Disappointed." Mainichi } \\
\text { "This is no good." Yomiuri " This is no good." }\end{array}$ \\
\hline 2012/11/30 & 33 & US Senate confirms duty to defend the Senkaku Islands. USA! USA! \\
\hline $2012 / 12 / 1$ & 2 & $\begin{array}{l}\text { Heizo Takenaka "Young people have the freedom to be poor. They should enjoy being poor." } \\
\text { (Takenaka is the former Finance Minister) }\end{array}$ \\
\hline $2012 / 12 / 1$ & 4 & Abe "We will use the latest technology to build new nuclear reactors at very safe sites." \\
\hline $2012 / 12 / 1$ & 12 & Why are Japanese news media politically biased and not neutral? \\
\hline $2012 / 12 / 1$ & 13 & Former PM Naoto Kan soapbox oratory really pitiful looking. \\
\hline $2012 / 12 / 1$ & 33 & (Same as item 2, but from a different blog.) \\
\hline 2012/12/1 & 43 & $\begin{array}{l}\text { Ishihara "Abolishing minimum wage? I don't know anything about that. I hate Takenaka, he's } \\
\text { the one that is writing this stuff." LOL }\end{array}$ \\
\hline $2012 / 12 / 1$ & 49 & My dad is a MP from the DPJ. Do you have any questions? \\
\hline 2012/12/2 & 19 & MP Doi former DPJ "I have always served for South Korea." \\
\hline $2012 / 12 / 2$ & 25 & MADOKA MAGICA political campaign \\
\hline $2012 / 12 / 2$ & 29 & Abe is officially revoking Kohno's comments during PM Miyazawa \\
\hline $2012 / 12 / 2$ & 34 & $\begin{array}{l}\text { Kada of the Tomorrow Party "Reinitiating nuclear power plants is like putting a thread through } \\
\text { a needle。" (Not a camel?) }\end{array}$ \\
\hline $2012 / 12 / 2$ & 38 & (Same as item 19, but from a different blog.) \\
\hline $2012 / 12 / 2$ & 49 & $\begin{array}{l}\text { Tomorrow Party "We shall provide } 26000 \text { yen per child!" Isn't that the same as DPJ } 3 \text { years } \\
\text { ago? }\end{array}$ \\
\hline $2012 / 12 / 3$ & & $\begin{array}{l}\text { PM Noda "Tomorrow Party's commitment of 312,000 yen per year per child doesn't say where } \\
\text { that money is going to come from. Unconvincing." }\end{array}$ \\
\hline $2012 / 12 / 3$ & 46 & Tomorrow Party and Social Democratic Party to cooperate for this coming election. LOL \\
\hline 2012/12/4 & 8 & PM Noda "Performs a back drop on Abe and puts him in a hold for him to tap out." \\
\hline $2012 / 12 / 4$ & 33 & LOL! The new LDP TV commercial! \\
\hline $2012 / 12 / 4$ & 45 & $\begin{array}{l}\text { DPJ Gen. Sec. Koshiishi the nutcase "Japan is being invaded by powers that will destroy } \\
\text { Japan." }\end{array}$ \\
\hline $2012 / 12 / 5$ & 11 & Unemployed, high school dropout running for Saitama 4th District LOL! \\
\hline $2012 / 12 / 5$ & 15 & $\begin{array}{l}\text { What kind of remote area has only four candidates? One each from the Komei, Communist, } \\
\text { Tomorrow and Happiness party? LOL! }\end{array}$ \\
\hline $2012 / 12 / 5$ & 25 & $\begin{array}{l}\text { Tomorrow Party may have broken the Public Offices Election Act by being late handing in their } \\
\text { list of candidates with their registration documents. }\end{array}$ \\
\hline $2012 / 12 / 5$ & 29 & $\begin{array}{l}\text { Abe criticizes abolishing nuclear reactors. "Irresponsible to make decisions without knowing } \\
\text { the results of clean energy development." }\end{array}$ \\
\hline $2012 / 12 / 5$ & 35 & $\begin{array}{l}\text { Asian nations "Why doesn't Japan expand their military when they are being threatened by } \\
\text { China like us? Can't understand this." }\end{array}$ \\
\hline $2012 / 12 / 5$ & 36 & Tokyo 1st district poster of "Jesus Matayoshi" who should commit "hara-kiri" and die. \\
\hline 2012/12/5 & 43 & DPJ candidate has DPJ in tiny letters in the bottom corner. LOL! \\
\hline $2012 / 12 / 6$ & 12 & (Same as item 15 from 2012/12/5, but from a different blog.) \\
\hline $2012 / 12 / 6$ & 19 & Scary stories from the Soviet Union. \\
\hline $2012 / 12 / 6$ & 20 & Takuro Morinaga "Why vote for LDP or Restoration Party? Everyone is against nuclear power \\
\hline
\end{tabular}




\begin{tabular}{|c|c|c|}
\hline & & and increasing taxes. Ignoring public opinion." \\
\hline $2012 / 12 / 6$ & 31 & DPJ Okada "Not a single leader on earth would just print money." Criticizes Abe. \\
\hline $2012 / 12 / 6$ & 45 & Comedian says "Let's vote. Don't complain if you don't vote. Blank ballots are meaningless." \\
\hline $2012 / 12 / 6$ & 49 & $\begin{array}{l}\text { Commentator Ikegami "Asking about Soka Gakkai to people in the Komei Party is not taboo." } \\
\text { TV Tokyo is the only channel for election night. }\end{array}$ \\
\hline $2012 / 12 / 7$ & 12 & LDP Satsuki Katayama "Our basic idea is to stop the thought of natural rights of humankind." \\
\hline $2012 / 12 / 7$ & 28 & UNIQLO President Yanai "Abe is no good because he has right wing characteristics." \\
\hline $2012 / 12 / 7$ & 30 & $\begin{array}{l}\text { Toru Hashimoto "Japan should put more effort into English language education. Even } \\
\text { kindergarten kids in the U.S. can speak English." }\end{array}$ \\
\hline $2012 / 12 / 7$ & 39 & $\begin{array}{l}\text { DPJ Hosono "Is there any MP from the LDP in their 40s that you think is good? I don't think } \\
\text { so." }\end{array}$ \\
\hline $2012 / 12 / 8$ & 16 & Horrible. Satire posters saying "Don't Trust Abe" found all over Tokyo. \\
\hline $2012 / 12 / 8$ & 37 & $\begin{array}{l}\text { PM Noda "During LDP era, wages kept decreasing, creating a working poor class. We will } \\
\text { create jobs." }\end{array}$ \\
\hline $2012 / 12 / 8$ & 38 & $\begin{array}{l}\text { China "Help! After we did Anti-Japanese demonstrations, we no longer can find employment! } \\
\text { Without Japanese companies, there is no employment." }\end{array}$ \\
\hline $2012 / 12 / 8$ & 48 & PM Noda bashes LDP daily. LDP "We're going to ignore Noda" LOL!! \\
\hline $2012 / 12 / 9$ & 7 & $\begin{array}{l}\text { Makiko Tanaka "Abe is a warmonger. Raise your hand and say yeah if you think the LDP is } \\
\text { good." Audience "Yeah!" "Yeah!" }\end{array}$ \\
\hline $2012 / 12 / 10$ & 2 & $\begin{array}{l}\text { Reiko Yukawa "If this National Defense Force plan becomes real, I will leave Japan with my } \\
\text { grandchildren." }\end{array}$ \\
\hline $2012 / 12 / 10$ & 23 & $\begin{array}{l}\text { PM Noda "Which party allowed South Korea to take over Takeshima? What kind of diplomacy } \\
\text { are you talking about? You can say that because you are an opposition party now." }\end{array}$ \\
\hline $2012 / 12 / 10$ & 25 & $\begin{array}{l}\text { Mainichi ERAVOTE (vote-matching site) users surprised with the superior policy of the } \\
\text { Happiness Realization Party }\end{array}$ \\
\hline $2012 / 12 / 10$ & 44 & $\begin{array}{l}\text { Philippines Foreign Minister welcomes Japan's military reinforcement. Requests Japan to } \\
\text { become an opponent of China. }\end{array}$ \\
\hline $2012 / 12 / 11$ & 20 & $\begin{array}{l}\text { Chinese BBS "The Japanese are brutes. How can you treat a former authority like that?" } \\
\text { Comments about the wretched Naoto Kan election campaign. }\end{array}$ \\
\hline $2012 / 12 / 11$ & 29 & $\begin{array}{l}\text { The prediction for Lower House Election of Tokyo is horrible. Forecasts Restoration Party to } \\
\text { have zero wins. }\end{array}$ \\
\hline $2012 / 12 / 12$ & 19 & Switzerland "Shouldn't Japan also become a neutral nation?" \\
\hline $2012 / 12 / 12$ & 34 & $\begin{array}{l}\text { Former PM Aso "Can't feel the heat, but the LDP is punching great numbers. What does this } \\
\text { mean? DPJ is much worse." }\end{array}$ \\
\hline $2012 / 12 / 12$ & 41 & $\begin{array}{l}\text { UNIQLO President Yanai "No global strategy with China." "Traitor!" "Pitiful words with such } \\
\text { narrow minds." }\end{array}$ \\
\hline $2012 / 12 / 13$ & 2 & Reminiscing the DPJ by cartoons. \\
\hline $2012 / 12 / 13$ & 5 & $\begin{array}{l}\text { Former PM Naoto Kan's campaign car has a traffic accident. Carried to hospital by } \\
\text { ambulance. }\end{array}$ \\
\hline $2012 / 12 / 14$ & 2 & $\begin{array}{l}\text { Ryuichi Sakamoto "We don't need to think of an alternative energy source, we just need to } \\
\text { oppose nuclear energy. Finding an alternative is the administration's job." }\end{array}$ \\
\hline $2012 / 12 / 14$ & 19 & $\begin{array}{l}\text { Restoration Party Ishihara "The } 1500 \text { trillion yen worth of savings and stocks of Japanese } \\
\text { citizens should be used effectively by the government." }\end{array}$ \\
\hline $2012 / 12 / 15$ & 3 & 2012 Election -Referential information for Supreme Court Justice Popular Review. \\
\hline $2012 / 12 / 16$ & 1 & Akira Ikegami's Election Special on TV Tokyo talks are wild. Popular topic. \\
\hline $2012 / 12 / 16$ & 5 & government. \\
\hline
\end{tabular}




\begin{tabular}{|c|c|c|}
\hline $2012 / 12 / 16$ & 13 & Shinjiro Koizumi is just too powerful. LOL! \\
\hline $2012 / 12 / 16$ & 20 & $\begin{array}{l}\text { Everyone who can vote is busy watching Purikyua in the morning, so the voter turnout is still } \\
\text { low before noon. }\end{array}$ \\
\hline $2012 / 12 / 16$ & 21 & Akira Ikegami: Probing into the Komei Party. LOL! \\
\hline $2012 / 12 / 16$ & 26 & Akira Ikegami's Election Live. The netizens are tumultuous. LOL! \\
\hline $2012 / 12 / 16$ & 32 & $\begin{array}{l}\text { Akira lkegami "You are called an insurgent old man because you treat other countries just like } \\
\text { North Korea." Ishihara "You listen to what I have to say. You are so rude. Who do you think you } \\
\text { are?" }\end{array}$ \\
\hline $2012 / 12 / 17$ & 2 & Ni-Channel Creator Hiroyuki vs. defeated anti-nuclear candidate Taro Yamamoto \\
\hline $2012 / 12 / 17$ & 6 & $\begin{array}{l}\text { Defeated anti-nuclear candidate Taro Yamamoto "Finished. Yes. Japan is finished. Let us all } \\
\text { escape from Japan." }\end{array}$ \\
\hline $2012 / 12 / 17$ & 8 & Cat that sees Shigeru Ishiba gets very excited and rowdy. \\
\hline $2012 / 12 / 17$ & 9 & Your Party Kakizawa refers animation to explain the election results. Detected an idiot. \\
\hline $2012 / 12 / 17$ & 12 & Makiko Tanaka defeated. Unsuccessful even with proportional representation seats. \\
\hline $2012 / 12 / 17$ & 23 & Akira Ikegami "Are all Komei Party candidates followers of Soka Gakkai?" \\
\hline $2012 / 12 / 17$ & 28 & Shnjiro Koizumi youngest minister. Yes!!! \\
\hline $2012 / 12 / 17$ & 30 & $\begin{array}{l}\text { Mass media "The LDP who have the Internet right wingers will lose. The Internet right wingers } \\
\text { don't reflect the public." - LDP landslide. LOL! }\end{array}$ \\
\hline $2012 / 12 / 17$ & 31 & Kan Naoto "The most irresponsible person is..." Audience "YOU!!" \\
\hline $2012 / 12 / 17$ & 34 & $\begin{array}{l}\text { LDP victory stock market index. Taro Aso's group corporation third highest increase in stock } \\
\text { price today. }\end{array}$ \\
\hline $2012 / 12 / 17$ & 36 & DPJ secessionists 1 win 70 losses "We must leave! We will lose if we stay in this party!" \\
\hline $2012 / 12 / 17$ & 39 & (Same as item 36, but from a different blog.) \\
\hline $2012 / 12 / 18$ & 8 & Abe "Tonight's dinner is at a hotel. I'm having the pork cutlet curry you all know about." \\
\hline $2012 / 12 / 18$ & 18 & Kubota "Will Abe bashing start again? Media are saying they will make him quit." \\
\hline $2012 / 12 / 18$ & 26 & (Same as item 18, but from a different blog.) \\
\hline $2012 / 12 / 18$ & 32 & $\begin{array}{l}\text { US CIA "Japan's trend towards conservatism is all propaganda from the Japanese leftists. } \\
\text { Revision of Article } 9 \text { is the hope of Asia." }\end{array}$ \\
\hline $2012 / 12 / 18$ & 34 & Asahi "DPJ must try their best to overcome and persevere until they regain power again." \\
\hline $2012 / 12 / 18$ & 35 & Russia "We will give you back the northern territories in 50 years, so let's be friends." \\
\hline $2012 / 12 / 18$ & 40 & Abe receives congratulations from all Asian nations except China and South Korea. \\
\hline $2012 / 12 / 19$ & 1 & Shukan Asahi (weekly magazine) cover page of Abe is horrible. \\
\hline $2012 / 12 / 19$ & 8 & Nikkei up 1800 yen since Noda dissolved parliament. Japanese stocks gain No. 1 globally. \\
\hline $2012 / 12 / 19$ & 36 & Anti-nuclear folk on Twitter have flipped after the election. Scary. LOL!!! \\
\hline $2012 / 12 / 20$ & 1 & For those of you who don't know if you are politically right or left. LOL!!!! \\
\hline $2012 / 12 / 20$ & 30 & Abe takes shots at Shukan Asahi (weekly magazine) on Facebook. Good job. \\
\hline $2012 / 12 / 20$ & 38 & Restoration Party "Teaming up with Ishihara was a mistake. We made poor judgment." \\
\hline $2012 / 12 / 20$ & 42 & (Same as item 38, but from a different blog.) \\
\hline
\end{tabular}




\section{About the Author}

Muneo Kaigo

Muneo Kaigo is an associate professor in the Faculty of Humanities and Social Sciences at the University of Tsukuba in Japan.

'The Japanese name for the forum, ni-channeru, has been translated variously into English as Channel 2, Ch2, the twochannel, the 2 Channel, or the $2 \mathrm{Ch}$. 